\title{
Electron Exchange Coupling in a Naturally Occurring Tetramangano Cluster in the Mineral Helvite, $\left(\mathrm{Mn}_{4} \mathrm{~S}\right)\left(\mathrm{SiBeO}_{4}\right)_{3}$
}

\author{
R. R. Sharp, W. M. Holloway, and P. G. Rasmussen \\ Department of Chemistry, The University of Michigan, Ann Arbor
}

\begin{abstract}
The mineral helvite, $\left(\mathrm{Mn}_{4} \mathrm{~S}\right)\left(\mathrm{BeSiO}_{4}\right)_{3}$, contains discrete tetrahedral $\mathrm{Mn}_{4} \mathrm{~S}^{+6}$ clusters in which the $\mathrm{S}^{-2}$ is tetrahedrally coordinated and each $\mathrm{Mn}$ (II) is in a distorted tetrahedron of one $\mathrm{S}^{-2}$ and three oxygens; the cluster is situated within an encompassing lattice of $\mathrm{SiO}_{4}^{-4}$ and $\mathrm{BeO}_{4}{ }^{-6}$ tetrahedra. $\mathrm{Mn}_{4} \mathrm{~S}^{+6}$ centers provide an interesting model for comparison to the polynuclear manganese center that is associated with photosynthetic water oxidation. Magnetic susceptibility data between 77 and $298 \mathrm{~K}$ have been measured for a natural helvite sample containing principally $\mathrm{Mn}_{4} \mathrm{~S}^{+6}$ centers but with significant contamination from $\mathrm{Mn}_{3} \mathrm{FeS}{ }^{+6}$ and $\mathrm{Mn}_{3} \mathrm{CaS}+6$. The data exhibited Curie-Weiss behavior with $\mu_{\text {eff }}=5.969$ B.M. and $\theta=178.3 \mathrm{~K}$. An analysis of the magnetic susceptibility, based on Van Vleck's formalism, demonstrated the presence of antiferromagnetic coupling, with a coupling constant $J=-5.83 \mathrm{~cm}^{-1}$. Mössbauer spectra of $\mathrm{Mn}_{3} \mathrm{FeS}$ centers in helvite and of $\mathrm{Fe}_{4} \mathrm{~S}$ centers in the related mineral danalite have also been recorded. Isomer shifts show little temperature dependence and lie in the range $1.23-1.43 \mathrm{~mm} / \mathrm{sec}$. This range is typical of tetrahedrally coordinated $\mathrm{Fe}$ (II) in several ionic crystals but is significantly above that of $\mathrm{Fe}$ (II) in ferredoxins and below that in the [quinone-Fe(II)-quinone] complex of the photosynthetic bacterium, Rhodopseudomonas sphaeroides. Quadrupole splittings are highly temperature dependent, ranging from $2.4 \mathrm{~mm} / \mathrm{sec}$ at $4.2 \mathrm{~K}$ to less than $0.5 \mathrm{~mm} / \mathrm{sec}$ at $248 \mathrm{~K}$.
\end{abstract}

\section{INTRODUCTION}

The catalytic site of photosynthetic water oxidation is associated with a polynuclear metal ion center containing manganese [1-19], possibly in conjunction with iron [20] or calcium [21]. The composition of the center and the identity of the manganese oxidation states in the catalytic cycle are not well established. Determinations of $\mathrm{Mn}$ (II) released by specific inactivators of water oxidation have

Address reprint requests to Dr. Robert R. Sharp, Department of Chemistry, University of Michigan, Ann Arbor, MI 48109. 
indicated a stoichiometry of approximately four manganese per Photosystem II (PSII) $[5,6,10,11,14]$, although a stoichiometry of $2 \mathrm{Mn} / \mathrm{PSII}$ has recently been inferred by Tris extraction of PSII particles [22]. During the catalytic oxidation of water, the manganese center (including its unknown bound intermediates) passes through a cycle of four photochemically induced oxidation states ( $S$-states) [23].

Specific spectroscopic signals have been linked to certain of these oxidation states. A multiline ESR signal has been detected from flash-illuminated thylakoid membranes and associated with the $S_{2}$ state [20, 24-28]. EXAFS diffraction patterns [29] and a flash-induced optical absorption near $315 \mathrm{~nm}$ [30-35] have also been linked to the manganese center. Quite recently, a broad $g=4.1$ absorption has been detected in ESR spectra of PSII preparations [20]. This transient signal has been attributed to rhombic Fe(III) in close association with the water oxidizing center.

The synthetic inorganic chemistry of manganese has provided very few model compounds to guide the interpretation of these data. Di- and tetranuclear complexes of manganese in di- $\mu$-oxo-bridged structures are known and have been analyzed extensively in relation to the multiline ESR signal of PSII $[36,37]$. These structures, which contain tightly exchange-coupled dimers and tetramers of $\mathrm{Mn}(\mathrm{III})$ and $\mathrm{Mn}$ (IV), form in aqueous media under highly oxidizing conditions [38, 39].

A second class of polynuclear manganese clusters occurs as tetranuclear manganese-sulfide centers in the mineral helvite. Helvite crystallizes hydrothermally as a silicate-berylate lattice which contains discrete tetrahedral $\mathrm{Mn}_{4} \mathrm{~S}^{+6}$

FIGURE 1. ORTEP drawing of the tetrahedral coordination spheres of $\mathrm{S}^{-2}$ and $\mathrm{Mn}^{2+}$ in the helvite structure. The geometry about $S^{-2}$ is strictly tetrahedral.

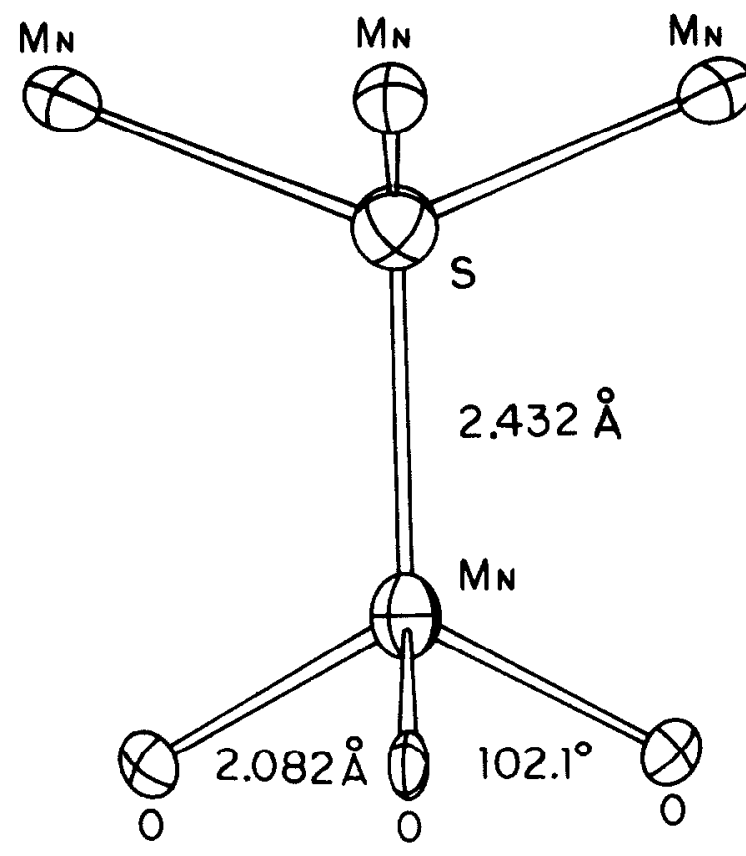


centers. ORTEP diagrams of the $\mathrm{Mn}_{4} \mathrm{~S}^{+6}$ center and of the helvite unit cell are shown in Figures 1 and 2. A sulfide ion acts as a common apex for four $\mathrm{MnO}_{3} \mathrm{~S}^{-6}$ tetrahedra. This produces the novel situation of four $\mathrm{Mn}(\mathrm{II})$ ions in perfect $T_{d}$ symmetry about a center $\mathrm{S}^{-2}$ ion. Individual $\mathrm{Mn}_{4} \mathrm{~S}^{+6}$ centers are separated by the surrounding lattice of silicate and berylate tetrahedra [40].

The degree of electron delocalization within the center has not been studied. The $\mathrm{Mn}$ (II)-Mn(I) distance is relatively long, $3.95 \AA$, suggesting that direct orbital overlap between metal ions is probably small. However, superexchange interaction transmitted via the central sulfide ion may be substantial.

Isomorphic replacement of $\mathrm{Mn}$ (II) by $\mathrm{Fe}(\mathrm{II}), \mathrm{Zn}$ (II), and $\mathrm{Ca}$ (II) occurs naturally in helvitelike minerals. The helvite and helvitelike structures comprise a series of tektosilicate minerals of the general formula $\left(\mathrm{M}_{4} \mathrm{~S}\right)\left(\mathrm{BeSiO}_{4}\right)_{3}$, where $\mathrm{M}$ represents a divalent metal jon. The three recognized end members of this series are helvite, $\mathbf{M}=\mathbf{M n}(\mathrm{II})$; danalite, $\mathbf{M}=\mathrm{Fe}(\mathrm{II})$; and genthelvite, $\mathbf{M}=\mathrm{Zn}(\mathrm{II})$. Natural minerals invariably exhibit intermediate compositions, often with $\mathrm{Ca}^{2+}$ substituting for $\mathrm{Zn}^{+2}$. The synthesis of crystals of pure helvite, $\left(\mathrm{Mn}_{4} \mathrm{~S}\right)\left(\mathrm{BeSiO}_{4}\right)_{3}$, has been reported in weakly acidic aqueous media under reducing conditions at elevated temperature and pressure [41].

FIGURE 2. ORTEP drawing of the helvite structure. Three-quarters of the unit cell projected on the (001) plane.

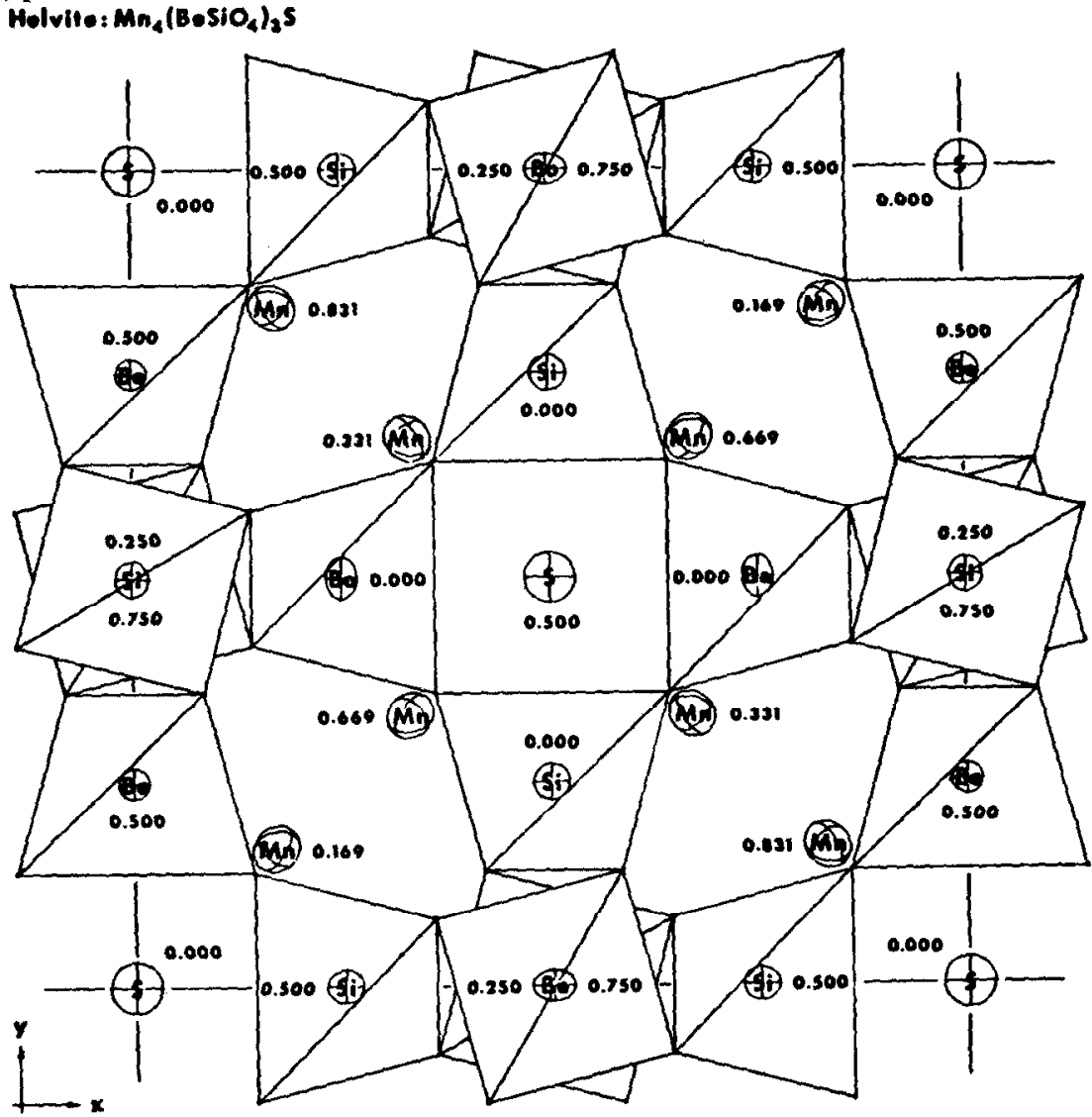


Electronic and magnetic properties of the $\mathrm{Mn}_{4} \mathrm{~S}^{+6}$ center have not previously been studied. In this communication we report the temperature-dependent paramagnetic susceptibility of helvite. From these data we have calculated the electronic exchange coupling of the $\mathrm{Mn}$ (II)-Mn(II) pair in $\mathrm{Mn}_{4} \mathrm{~S}^{+6}$ centers using Van Vleck's formalism [42]. Determination of the electron exchange coupling within these clusters seemed a promising approach to the experimental differentiation of di- $\mu$-oxo- and $\mathrm{S}^{-2}$-bridged polynuclear manganese clusters. Exchange couplings in di- $\mu$-oxo-bridged structures are typically large, of order $-150 \mathrm{~cm}^{-1}$, while those for $\mathrm{Mn}$ (II) in $\mathrm{S}^{-2}$-bridged lattices (such as cubic $\beta$-MnS) are generally much smaller $(-5)-(-10) \mathrm{cm}^{-1}$. The results suggest that static magnetic measurements of purified PSII particles poised in specific $S$-states may provide a useful basis for probing the nature of bridging ligands in the water-oxidizing center.

In addition, Mössbauer and ESR spectra have been obtained to provide spectroscopic signatures of the metal ion site in $\mathrm{M}_{4} \mathrm{~S}^{+6}$ centers. These studies have utilized the different end members of the helvite/danalite/genthelvite triad to obtain metal compositions suitable for study.

\section{EXPERIMENTAL}

The helvite specimen was obtained from the University of Michigan Mineralogical Collection. Yellow, or pale greenish-yellow, tetrahedral crystals (up to $2.0 \mathrm{~mm}$ on an edge) encrusted on a fine-grained gray-colored matrix characterized the sample from Schwarzenberg, in Saxony, Germany, the type locality for the mineral. Helvite obtained from this specimen was used both in the structure refinement [40] and in this work. The crystalline material was manually separated from the matrix and finely ground, using an agate mortar and pestle, for use in the susceptibility studies.

Electron microprobe analysis indicated the nonframework metal ion site occupancy at this specimen to be $\mathrm{Mn}(\mathrm{II}), 72.2 \%$; $\mathrm{Fe}(\mathrm{II}), 14.3 \%$; Ca(II), $8.7 \%$; $\mathrm{Co}(\mathrm{II}), 1.6 \%$; $\mathrm{Cu}(\mathrm{II}), 1.6 \%$; and $\mathrm{Zn}(\mathrm{II}), 1.6 \%$. This analysis is equivalent to having 7.18 paramagnetic metal ions out of 8.00 possible nonframework metal ions in the crystallographic unit cell.

The variable temperature magnetic susceptibility measurements were performed on a Faraday magnetic balance, which has been described in detail elsewhere [43]. Susceptibility data were collected at six temperatures: 77.2, 92.1, 104.9, 117.4, 135.7 and $296.5 \mathrm{~K}$. At least four separate weight measurements were made at each temperature for the bucket, the standard and the sample at each of three different magnetic field strengths. For each set of weight measurements, the individual weights agreed within $\pm 0.1 \mu \mathrm{g}$. The standard used for these measurements was nickel(II) ammonium sulfate hexahydrate, $\left(\mathrm{NH}_{4}\right)_{2} \mathrm{Ni}\left(\mathrm{SO}_{4}\right)_{2} \cdot 6 \mathrm{H}_{2} \mathrm{O}$, for which the gram susceptibility value was given by Simmons [44].

An ESR spectrum of powdered helvite at ambient temperature gave a single very broad absorption (approximately $3750 \mathrm{G}$ wide). The lack of the expected six-line hyperfine arising from the ${ }^{55} \mathrm{Mn}$ nucleus $(100 \%$ natural abundance, $I=5 / 2)$ and the breadth of the spectrum suggested that exchange interactions may be present in this mineral. The value of $g$ for this absorption is approximately 2.0 , although the breadth precluded an accurate measurement. 


\section{MÖSSBAUER STUDIES}

Room temperature Mössbauer spectra were obtained using a ${ }^{57} \mathrm{Co}$ source (New England Nuclear) with a spectrometer constructed in the Department of Nuclear Engineering of the University of Michigan [45, 46]. Low-temperature spectra were collected using a different instrument through the courtesy of Dr. W. Richard Dunham of the Biophysics Research Division of the University of Michigan [47]. Samples contained 45-50 mg of powdered materials prepared as described above. The velocity calibration was provided by sodium nitroprusside, $\mathrm{Na}_{2}(\mathrm{Fe}$ $\left.(\mathrm{CN})_{5} \mathrm{NO}\right) \cdot 2 \mathrm{H}_{2} \mathrm{O}$, using a value of $1.726 \mathrm{~mm} / \mathrm{sec}$ for the quadrupole splitting.

Spectral simulations were carried out with the aid of the program MFIT, written by Gould [45]. The simulations assumed that each spectrum comprised a symmetric Lorenzian doublet. The program iterated on the isomer shift, the quadrupole splitting, the linewidth, and intensity.

\section{RESULTS}

\section{Magnetic Susceptibilities}

Magnetic susceptibilities, $\chi_{m}$, for helvite were measured over a range of temperatures from 77.2 to $297 \mathrm{~K}$. These values were converted to atomic susceptibilities, $\chi_{A}=\chi_{m} / N_{p}$, where $N_{p}$ is the number of paramagnetic ions per unit cell. The electron microprobe analysis (see above) gave a value of $N_{p}=7.18$ for the helvite sample used. $\chi_{A}$ values are tabulated in Table 1. A plot of $1 / \chi_{A}$ against temperature is shown in Figure 3. The data follow a Curie-Weiss law, $\chi_{A}{ }^{-1}=C /(T-\theta)$, where the Curie constant $C=N \beta^{2} \mu_{\text {eff }}{ }^{2} / 3 k . N$ is Avogadro's

TABLE 1. Magnetic Properties of Helvite

\begin{tabular}{cccc}
\hline $\begin{array}{c}\text { Temperature } \\
(k)\end{array}$ & $\begin{array}{c}\chi_{A}{ }^{a} \\
\left(10^{-6} \mathrm{cgs}\right)\end{array}$ & $\begin{array}{c}\mu_{\text {eff }}{ }^{b} \\
(\mathrm{~B} . \mathrm{M} .)\end{array}$ & $\begin{array}{c}\mu_{\text {cal }}{ }^{c} \\
(\mathrm{B.M} .)\end{array}$ \\
\hline 77.2 & $17735(41)$ & $3.309(0.011)$ & 3.294 \\
92.1 & $16370(78)$ & $3.472(0.014)$ & 3.499 \\
104.9 & $15664(87)$ & $3.625(0.016)$ & 3.649 \\
117.4 & $14984(102)$ & $3.751(0.017)$ & 3.776 \\
135.7 & $14087(164)$ & $3.910(0.026)$ & 3.934 \\
296.5 & $9391(99)$ & $4.719(0.025)$ & 4.719 \\
$\mu_{\text {eff }}{ }^{d}$ & $5.966 \pm 0.019$ B.M. & \\
$\theta^{d}$ & $178.3 \mathrm{~K}$ & &
\end{tabular}

\footnotetext{
a $\chi_{A}=$ atomic susceptibility calculated assuming the number of paramagnetic ions per unit cell was 7.18 .

${ }^{b} \mu_{\text {eff }}=$ effective magnetic moment calculated assuming Curie law behavior.

${ }^{c} \mu_{\text {cal }}=$ magnetic moment calculated assuming exchange behavior averaged over the cluster models discussed in the text.

${ }^{d} \mu_{\text {eff }}=$ average effective magnetic moment calculated assuming Curie-Weiss law behavior, $\mu_{\mathrm{et1}}=2.828\left[\chi_{A}(T+\right.$ $\theta)]^{1 / 2}$.
} 


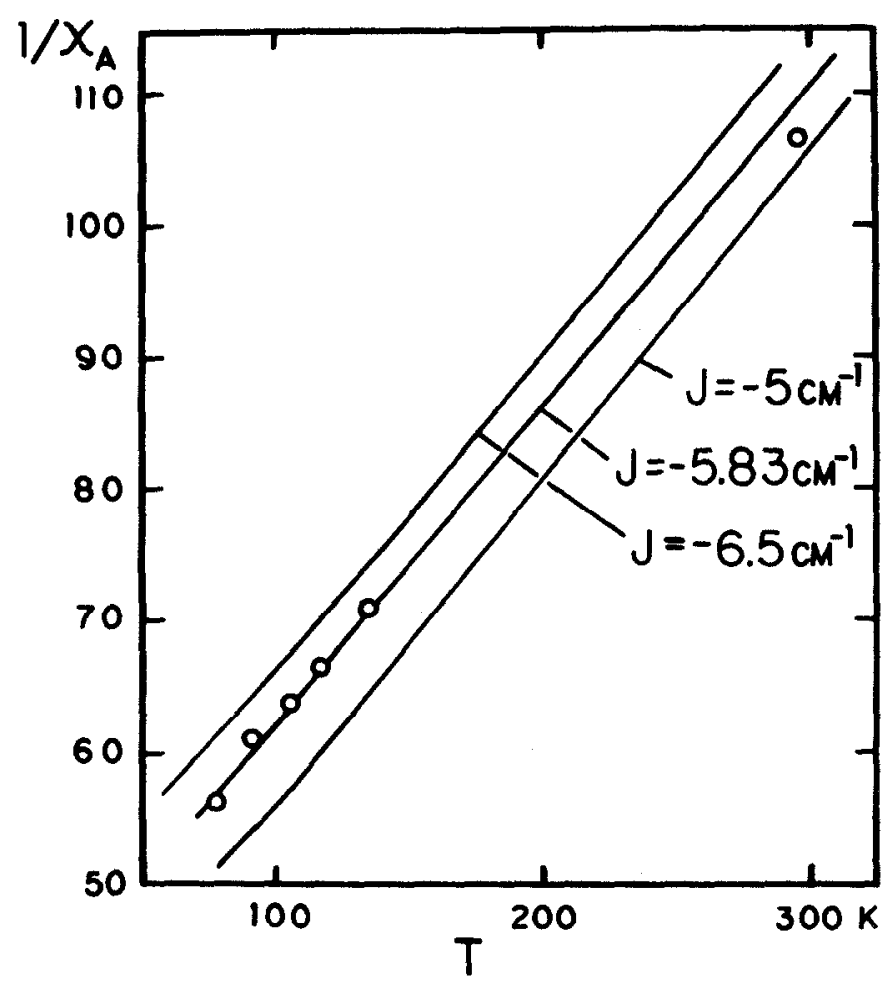

FIGURE 3. Reciprocal magnetic susceptibility per paramagnetic ion of helvite as a function of temperature. Solid lines are theoretical curves calculated as described in the text.

number, $\beta$ is the Bohr magneton, $\mu_{\text {eff }}$ is the effective magnetic moment in B.M., and $k$ is Boltzmann's constant. A least-squares analysis gave values of 5.966 B.M. and $178.3 \mathrm{~K}$, respectively, for $\mu_{\text {eff }}$ and $\theta$. The value of $\mu_{\text {eff }}$ agrees with the hightemperature spin-only magnetic moment of an $S=5 / 2$ ion, 5.92 B.M. The large magnitude of $\theta$ indicates the presence of substantial exchange coupling in the $\mathrm{Mn}_{4} \mathrm{~S}$ centers.

The theoretical basis for calculating the magnetic susceptibility is described fully in monographs by Earnshaw [48], Figgis [49], Selwood [50], Val Vleck [42], and Mabbs [51]. $\chi_{m}$ for a cluster of exchange-coupled metal ions is computed by summing over all thermally accessible states with total spin quantum number $S_{T}$ :

$$
\begin{gathered}
\chi_{m}=\frac{N \beta^{2} g^{2}}{3 R T} \frac{\sum_{S_{T}} A\left(S_{T}\right) \exp \left[-E\left(S_{T}\right) / k T\right]}{\sum_{S_{T}} B\left(S_{T}\right) \exp \left[-E\left(S_{T}\right) / k T\right]} \\
A\left(S_{T}\right)=S_{T}\left(S_{T}+1\right)\left(2 S_{T}+1\right) r\left(S_{T}\right) \\
B\left(S_{T}\right)=\left(2 S_{T}+1\right) r\left(S_{T}\right)
\end{gathered}
$$

where $g$ is the splitting factor, $E=J m_{s 1} m_{s 2}$ is the electron exchange coupling energy, $m_{s i}$ is the magnetic quantum number of spin $i$, and $r\left(S_{T}\right)$ is a degeneracy factor [48]. 
The calculation of $\chi_{m}$ for helvite is complicated by the presence of substantial concentrations of three different metal ions, $\mathrm{Mn}$ (II) $(72.2 \%), \mathrm{Fe}$ (II) (14.1\%) and diamagnetic ions, $\mathrm{D}\left(10.4 \%\right.$, largely as $\left.\mathrm{Ca}^{+2}\right)$ in the natural crystal. It is therefore necessary to average the susceptibility over a statistical distribution of $\mathbf{M}_{4} \mathrm{~S}$ centers. The main clusters present are $\mathrm{Mn}_{4} \mathrm{~S}(27.2 \%), \mathrm{Mn}_{3} \mathrm{Fe}(21.5 \%), \mathrm{Mn}_{3} \mathrm{D}$ (15.7\%), $\mathrm{Mn}_{2} \mathrm{FeD}(9.0 \%)$, and $\mathrm{Mn}_{2} \mathrm{D}_{2}$ (3.3\%). Explicit theoretical expressions for $\chi_{A}$ appropriate to each of these clusters are given in Table 2 . The expressions have been derived from equation (1) assuming a single average exchange integral in the different centers. Other cluster types, such as $\mathbf{M n}_{2} \mathrm{Fe}_{2}$, are also present at low concentration. For the purposes of calculation, these were represented by the most similar of the tabulated cluster types.

$\chi_{A}$ has been calculated as a function of temperature, with systematic variation of $J$, which was determined by a least-squares fit to the experimental data. In these calculations, $g$ was taken to be $\mathbf{2 . 0}$ as appropriate for the orbital singlet ground state of $\mathrm{Mn}$ (II). Corrections for diamagnetic susceptibility and for orbital contributions to the magnetic moment of Fe(II) were neglected. The results are summarized in Table 1 , which contains values of $\chi_{A}$ and $\mu_{\text {eff }}$ calculated from equation (1), as well as $\mu_{\text {eff }}$ calculated from the Curie-Weiss law. A comparison of experiment and theory is also shown in Figure 3, where $\chi_{A}{ }^{-1}$ is plotted against temperature for three different values of $J: J=-5.00 \mathrm{~cm}^{-1},-5.83 \mathrm{~cm}^{-1}$, and $6.50 \mathrm{~cm}^{-1}$. A least-squares best fit to the data was found at $J=-5.83 \mathrm{~cm}^{-1}$. This confirms the presence of significant exchange couplings within the $\mathrm{M}_{4} \mathrm{~S}$ center.

\section{Mössbauer Spectroscopy}

Mössbauer spectra of ${ }^{57} \mathrm{Fe}$ in helvite and danalite were recorded at 297,77 , and 4.2 $\mathrm{K}$ and are shown in Figures 4 and 5 . The helvite spectra arise largely from $\left(\mathrm{Mn}_{3} \mathrm{Fe}\right) \mathrm{S}$ centers, which are the major iron-containing cluster species in this mineral. The room temperature spectra consist of broad singlets, which resolve into quadrupole doublets at lower temperatures. Simulations of the spectra yielded the parameters shown in Table 3 . The room temperature spectra were fitted to an unresolved quadrupole pair of absorptions.

The isomer shifts observed for helvite and danalite are in good agreement with those reported previously for minerals containing $\mathrm{Fe}$ (II) in a tetrahedral site. For example, Bankcroft, Maddock, and Burns [52] reported isomer shifts of 1.26 and $1.30 \mathrm{~mm} / \mathrm{sec}$ for two samples of the mineral Staurolite, which has $\mathrm{Fe}$ (II) in a distorted tetrahedral site. They also agree reasonably well with those of $\mathrm{Fe}$ (II) in the reduced form of ferredoxins from spinach and chromatium [53]. The observed quadrupole splittings are markedly temperature dependent, ranging from less than 0.5 to $2.43 \mathrm{~mm} / \mathrm{sec}$ as the temperature drops from 297 to $4.2 \mathrm{~K}$. These splittings measure the distortion from tetrahedral symmetry of the Fe(II) site. The electronic symmetry about $\mathrm{Fe}(\mathrm{II})$ is strongly temperature dependent and approaches a cubic environment at room temperature.

\section{DISCUSSION}

Tetrahedral stereochemistry is quite rare in the aqueous coordination chemistry of Mn(II). Under anhydrous conditions, however, a number of tetrahalide anions are 
TABLE 2. Theoretical Expressions for the Magnetic Susceptibilities of $M_{4} S$ Centers Considered in the Calculation of the Susceptibility of Helvite ${ }^{a}$

$$
\begin{aligned}
& \begin{array}{c}
\text { Tetrahedral, } \\
\text { Mn }(11)_{4}
\end{array} \chi_{A}= \\
& \frac{K}{2 T}\left[\frac{385 \exp (-110 x)+855 \exp (-90 x)+1224 \exp (-72 x)}{7 \exp (-110 x)+19 \exp (-90 x)+34 \exp (-72 x)}\right. \\
& \frac{+1400 \exp (-56 x)+1365 \exp (-42 x)+1155 \exp (-30 x)}{+50 \exp (-56 x)+65 \exp (-42 x)+77 \exp (-30 x)} \\
& \frac{+720 \exp (-20 x)+336 \exp (-12 x)+105 \exp (-6 x)}{+72 \exp (-20 x)+56 \exp (-12 x)+35 \exp (-6 x)} \\
&+15 \exp (-2 x) \\
&+15 \exp (-2 x)+2
\end{aligned}
$$

Tetrahedral, $\mathrm{Mn}(\mathrm{II})_{3} \mathrm{Fe}$ (II)

$$
\begin{aligned}
\chi_{A}= & \frac{3 K}{16 T}\left[\frac{969 \exp (-80 x)+2040 \exp (-63 x)+2730 \exp (-48 x)}{9 \exp (-80 x)+24 \exp (-63 x)+42 \exp (-48 x)}\right. \\
& +\frac{+2860 \exp (-35 x)+2475 \exp (-24 x)+1512 \exp (-15 x)}{+60 \exp (-35 x)+75 \exp (-24 x)+72 \exp (-15 x)} \\
& +630 \exp (-8 x)+150 \exp (-3 x)+9 \\
& +54 \exp (-8 x)+30 \exp (-3 x)+9
\end{aligned}
$$

Trigonal,

$\mathrm{Mn}(\mathrm{II})_{3}$

$$
\begin{aligned}
\chi_{A}= & \frac{K}{4 T}\left[\frac{340 \exp (-63 x)+455 \exp (-48 x)+429 \exp (-35 x)}{4 \exp (-63 x)+7 \exp (-48 x)+9 \exp (-35 x)}\right. \\
& \frac{+330 \exp (-24 x)+210 \exp (-15 x)+105 \exp (-8 x)}{+10 \exp (-24 x)+10 \exp (-15 x)+9 \exp (-8 x)} \\
& \left.\frac{+20 \exp (-3 x)+1}{+4 \exp (-3 x)+1}\right]
\end{aligned}
$$

Trigonal,

$\mathrm{Mn}(\mathrm{II})_{2} \mathrm{Fe}$ (II)

$$
\begin{aligned}
\chi_{A}= & \frac{K}{4 T}\left[\frac{455 \exp (-48 x)+572 \exp (-35 x)}{7 \exp (-48 x)+12 \exp (-35 x)}\right. \\
& \frac{+495 \exp (-24 x)+336 \exp (-15 x)}{+15 \exp (-24 x)+16 \exp (-15 x)} \\
& \left.\frac{+175 \exp (-8 x)+40 \exp (-3 x)+2}{+15 \exp (-8 x)+8 \exp (-3 x)+2}\right]
\end{aligned}
$$

Linear,

$\mathrm{Mn}(\mathrm{II})_{2}$

$$
\begin{aligned}
\chi_{A}= & \frac{3 K}{T}\left[\frac{55 \exp (-30 x)+30 \exp (-20 x)+14 \exp (-12 x)}{11 \exp (-30 x)+9 \exp (-20 x)+7 \exp (-12 x)}\right. \\
& \left.\frac{+5 \exp (-6 x)+\exp (-2 x)}{+5 \exp (-6 x)+3 \exp (-2 x)+1}\right]
\end{aligned}
$$

a Mole percents of the clusters present in the helvite sample used in this study are given. Expressions are derived from equation (1) of the text by summing over all states of total spin, $S_{T}$, where $K=N \beta^{2} g^{2} / 3 k$ and $x=-J / k T$. 


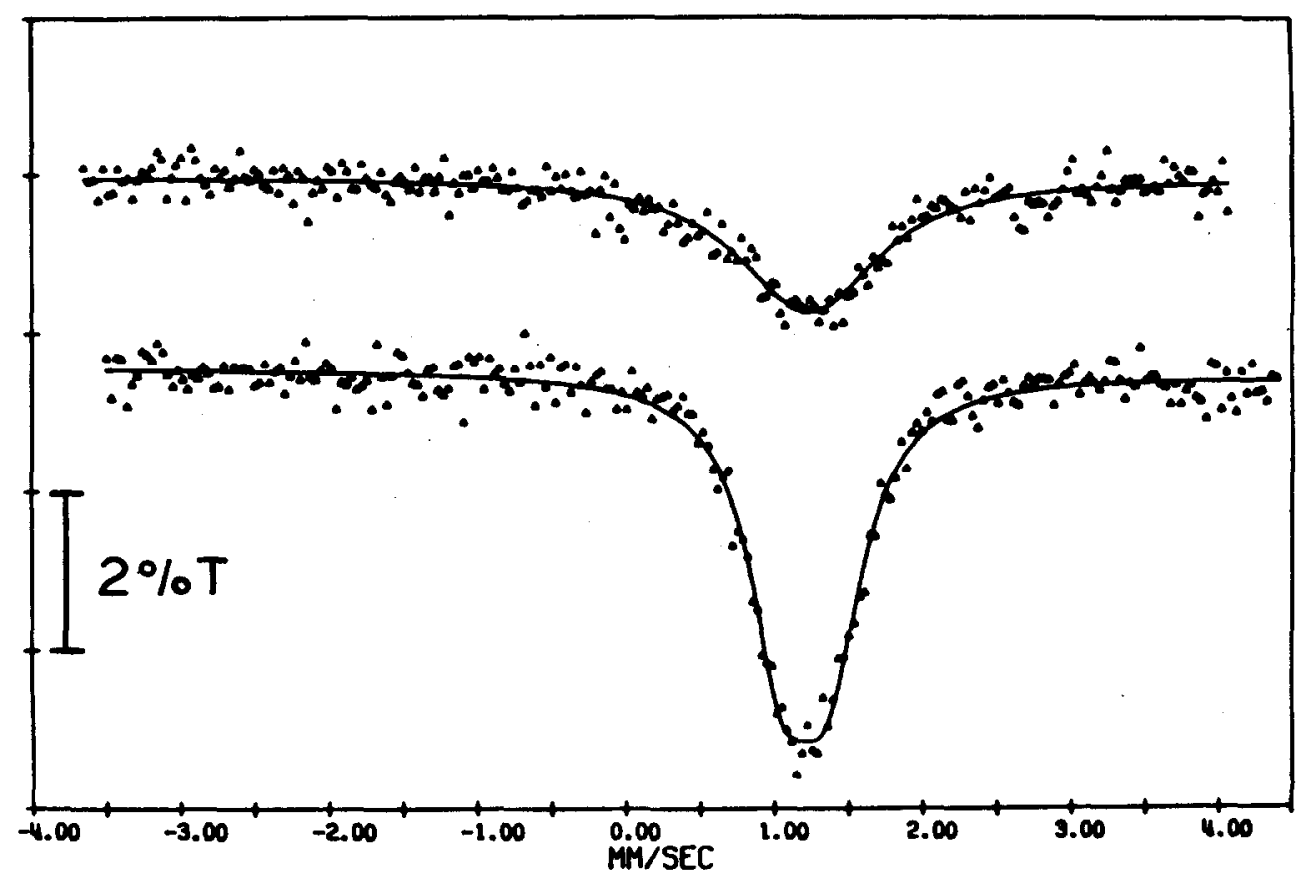

FIGURE 4. Mössbauer spectra of ${ }^{57} \mathrm{Fe}$ in helvite (upper) and danalite (lower) at $298 \mathrm{~K}$. The helvite sample contained $14.6 \% \mathrm{Fe}$, and the spectrum is predominantly of the $\left(\mathrm{Mn}_{3} \mathrm{Fe}\right) \mathrm{S}$ center. Solid lines are simulations of the spectra using the program MFIT [42].

FIGURE 5. Mössbauer spectra of ${ }^{57} \mathrm{Fe}$ in danalite at $77 \mathrm{~K}$ (upper) and $4.2 \mathrm{~K}$ (lower).

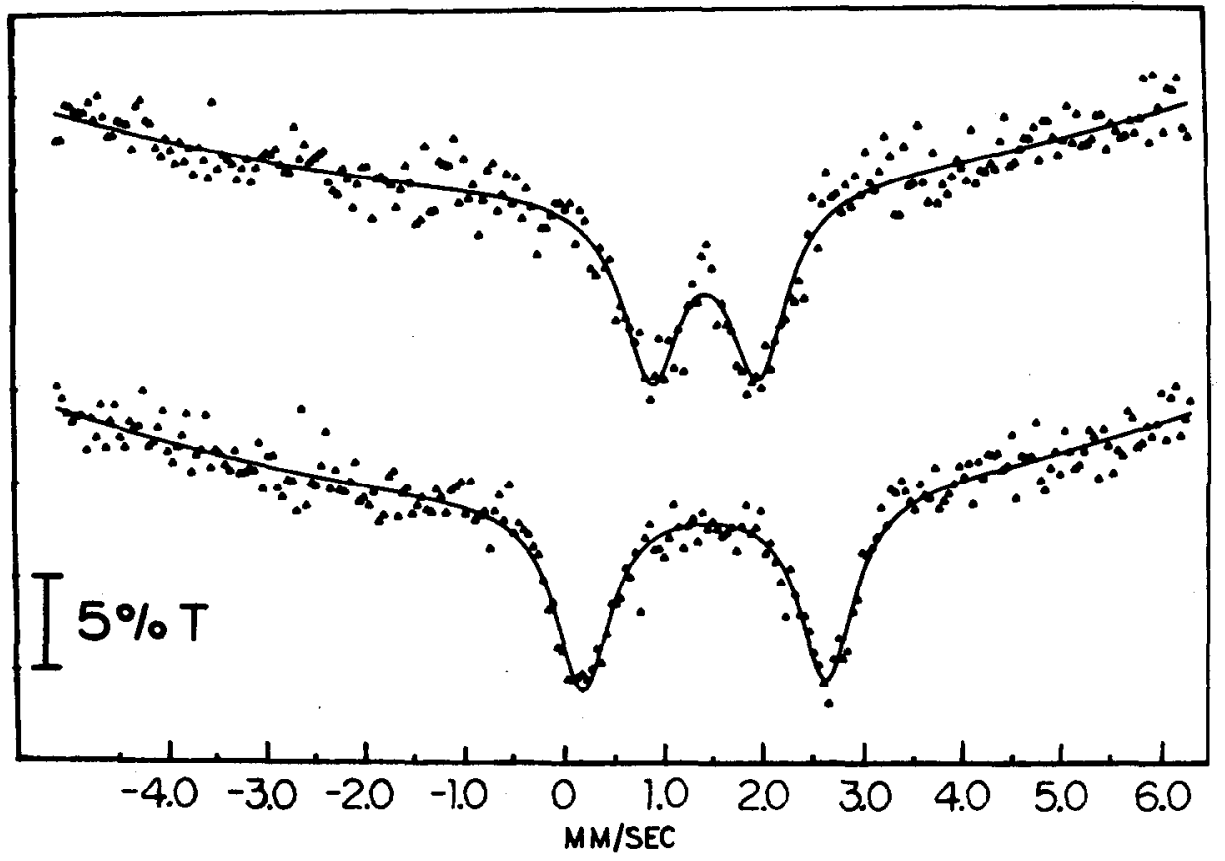


TABLE 3. Mössbauer Spectral Parameters of Helvite, $\left(\mathrm{Mn}_{3} \mathrm{FeS}\right)\left(\mathrm{BeSiO}_{4}\right)_{3}$ and Danalite, $\mathrm{Fe}_{4} \mathrm{~S}\left(\mathrm{BeSiO}_{4}\right)_{3}^{a}$

\begin{tabular}{lcrr}
\hline Sample & $\begin{array}{c}\text { Temperature } \\
\text { (K) }\end{array}$ & $\begin{array}{c}\text { Isomer } \\
\text { shift }\end{array}$ & $\begin{array}{c}\text { Quadrupole } \\
\text { splitting }\end{array}$ \\
\hline Helvite $\left(\mathrm{Mn}_{3} \mathrm{Fe}\right) \mathrm{S}$ & 296 & 1.28 & $<0.50$ \\
Helvite $\left(\mathrm{Mn}_{3} \mathrm{Fe}\right) \mathrm{S}$ & 77 & 1.43 & 1.14 \\
Danalite $\left(\mathrm{Fe}_{4} \mathrm{~S}\right)$ & 298 & 1.23 & $<0.50$ \\
Danalite $\left(\mathrm{Fe}_{4} \mathrm{~S}\right)$ & 77 & 1.41 & 1.06 \\
Danalite $\left(\mathrm{Fe}_{4} \mathrm{~S}\right)$ & 4.2 & 1.39 & 2.43 \\
\hline
\end{tabular}

a The iron content of the helvite sample is 14.3 atom percent of transition metal ions.

formed: these comprise $\mathrm{MnX}_{4}{ }^{-2}$ and $\mathrm{MnL}_{2} \mathrm{X}_{2}$ structures, with $\mathrm{X}$ being a halide anion and $\mathrm{L}$ a Lewis base such as pyridine, acetonitrile, or certain phosphines. Only a few of these are tetrahedral, the rest being octahedral polymers with halide bridges. $\mathrm{Mn}(\mathrm{II})$ is also found in tetrahedral sites in some glasses and in some crystalline compounds replacing $\mathrm{Zn}$ (II). The $\mathrm{Mn}_{4} \mathrm{~S}^{+6}$ centers of helvite thus represent a highly unusual coordination geometry, which appeared to be of interest from several standpoints.

First among these is the metal ion stoichiometry of four manganese ions per center, which coincides with most determinations of the manganese content of PSII. The conditions under which the centers form (hydrothermal deposition from weakly acidic, aqueous media [54]) also suggested that such centers could exist in stable equilibrium with the weakly acidic aqueous phase of the thylakoid lumen. Chemically, $\mathrm{Mn}_{4} \mathrm{~S}^{+6}$ appear to be described best as predominantly ionic clusters. The $\mathrm{Mn}-\mathrm{S}$ bond distance in helvite $(2.432 \AA$, Fig. 1) is in close agreement with the $\mathrm{Mn}-\mathrm{S}$ distance of $2.427 \AA$ found in $\beta$-MnS [55], which has the zinc blende lattice. The bond distance is also close to the sum of ionic radii. An ionically bonded $\mathrm{Mn}_{4} \mathrm{~S}^{+6}$ center is expected to show considerable lability. In this regard, it is noteworthy that the water-oxidizing center dissociates reversibly under mild denaturating conditions, including brief temperature shock at $50^{\circ} \mathrm{C}[56-58]$, high concentrations of Tris buffer [56-58, 14] exposure to alkaline $\mathrm{pH}$ [59]. Spontaneous reconstitution of water-oxidizing activity after each of these treatments has been demonstrated in the acid medium of the thylakoid lumen in the presence of reductants (e.g., ascorbate, propylgallate), $\mathrm{Mn}$ (II), and light [56-58, 14]. However, it should also be noted that a previous EXAFS study of thylakoid membranes [20] did not find a diffraction contribution consistent with the ionic $\mathrm{Mn}(\mathrm{II})-\mathrm{S}^{-2}$ distance.

The magnetic properties of helvite have been described successfully in terms of a statistical distribution of $\mathrm{M}_{4} \mathrm{~S}^{+6}$ centers, with moderate antiferromagnetic exchange coupling $\left(J=-5.8 \mathrm{~cm}^{-1}\right)$ between paramagnetic metal ions. This magnitude for $J$ is consistent with values found in a variety of crystals that contain tetrahedral $\mathrm{Mn}$ (II) with bridging sulfide ligands (Table 4). On the other hand, the observed exchange coupling is much smaller than that of tetrahedrally coordinated 
TABLE 4. Exchange Parameters for Manganese (II) in Tetrahedral Environments

\begin{tabular}{lccc}
\hline \multicolumn{1}{c}{ Compound } & $J\left(\mathrm{~cm}^{-1}\right)$ & $g$ & Reference \\
\hline $\mathrm{Mn}_{4}\left(\mathrm{BeSiO}_{4}\right)_{3} \mathrm{~S}$ & -5.83 & 2.00 & This work \\
$\mathrm{Ba}_{2} \mathrm{MnS}_{3}$ & -8.55 & 2.00 & 67 \\
$\mathrm{Ba}_{2} \mathrm{MnSe}_{3}$ & -6.81 & 2.03 & 67 \\
$\beta-\mathrm{MnS}_{3}(\mathrm{cubic})$ & -8.62 & 2.00 & 68 \\
$\beta-\mathrm{MnS}($ hexagonal $)$ & -7.44 & 2.00 & 68 \\
MnSiZnS & -9.00 & 2.00 & 69 \\
MnSiZnS & -9.00 & 2.00 & 70 \\
\hline
\end{tabular}

$\mathrm{Fe}(\mathrm{II})$ in the $2 \mathrm{Fe}-2 \mathrm{~S}$ ferredoxins [60]. In the reduced form of spinach ferredoxin, $J$ is approximately $-100 \mathrm{~cm}^{-1}$. Antiferromagnetic coupling is also much greater in di- $\mu$-oxo-bridged $\mathrm{Mn}$ (III, IV) dimers than in the $\mathrm{Mn}_{4} \mathrm{~S}^{+6}$ center. For di- $\mu$-oxotetrakis( $2,2^{\prime}$-bipyridine)dimanganese (III, IV) perchlorate dihydrate, $J \cong-150$ $\mathrm{cm}^{-1}[61,62]$. This difference is consistent with measured bond distances in these clusters. The Mn-O-Mn bridge is strongly covalent as judged by the $\mathrm{MnO}$ bond distance (1.78-1.85 $\AA$ [62]), whereas the Mn-S-Mn bridge is largely ionic (see above). The large measured difference in exchange couplings suggests an experimental basis for differentiating di- $\mu$-oxo-bridged and $\mathrm{S}^{-2}$-bridged structures.

We have found no evidence of significant exchange coupling between neighboring $\mathrm{Mn}_{4} \mathrm{~S}^{+6}$ centers in helvite. The room temperature EPR spectrum of $\left(\mathrm{Zn}_{3} \mathrm{MnS}\right)$ centers in the $\mathrm{Zn}$-rich end-number genthelvite has been recorded (not shown) and exhibits several groups of well-resolved hyperfine multiplets. These highly resolved spectra argue against the presence of significant long-range magnetic couplings. In contrast, the room temperature ESR spectrum of the Mn-rich end member, helvite, is broad and featureless.

The observed quadrupole splittings are strongly temperature dependent. $\Delta E_{Q}$ becomes unresolvably small at room temperature, indicating effective tetrahedral symmetry in the electron distribution. This high symmetry is also reflected in the room temperature ESR spectrum of genthelvite, which contains highly resolved fine and hyperfine structure.

Mössbauer spectra of the $\mathrm{Fe}(\mathrm{II})_{4} \mathrm{~S}^{+6}$ cluster of danalite and the $\mathrm{Mn}_{3} \mathrm{FeS}+6$ cluster of helvite were recorded in order to characterize the $\mathrm{Fe}$ (II) site of these centers and to examine the possibility that Mössbauer spectra would provide a distinctive signature of the structure. The ${ }^{57} \mathrm{Fe}$ isomer shifts of helvite and danalite lie in the range $1.28-1.43 \mathrm{~mm} / \mathrm{sec}$, which is normal for tetrahedrally coordinated $\mathrm{Fe}$ (II) in ionic crystals. Isomer shifts of ferredoxins are somewhat lower, ranging from about $+0.0-0.3 \mathrm{~mm} / \mathrm{sec}$ in the oxidized protein to slightly higher values in the reduced form $[63,64]$. Another interesting structure for comparative purposes is the $\mathrm{Q}-\mathrm{Fe}(\mathrm{II})-\mathrm{Q}(\mathrm{Q}=$ ubiquinone) complex found in reaction centers of the photosynthetic bacterium $R$. sphaeroides [65]. An analogous complex has been demonstrated on the reducing side of PSII in higher plants [66]. Fe(II), which is present exclusively in the ferrous oxidation state in this complex, exhibits isomer 
shifts in the range $1.83 \mathrm{~mm} / \mathrm{sec}(190 \mathrm{~K})$ to $2.19 \mathrm{~mm} / \mathrm{sec}(4.2 \mathrm{~K})$. These values are shifted significantly to high velocity of those in $\mathrm{Mn}_{3} \mathrm{FeS}^{+6}$ and are typical of octahedral ferrous complexes.

Clearly, we cannot at this time offer the helvite manganese cluster as a model for the photosynthetic manganese system. It is intriguing, however, that this system occurs in nature, and that it forms under relatively mild conditions. We have characterized its properties, to extend the range of possibilities that are considered for model systems, to call attention to a structural motif for manganese that has not yet been observed in synthetic systems, and to provide suitable data for comparison purposes with other natural and synthetic clusters.

The kind assistance of Dr. Dietrich H. Vincent of the Department of Nuclear Engineering of the University of Michigan and of Dr.W.R. Dunham of the Biophysics Research Division of the University of Michigan during the Mössbauer experiments is gratefully acknowledged. Partial financial support was received from the U.S. Department of Agriculture in the form of a grant to RRS (No. 82-CRCR-1-1047).

\section{REFERENCES}

1. G. M. Cheniae and I. F. Martin, Plant Physiol. 47, 568-575 (1971).

2. G. M. Cheniae, Methods Enzymol. 69, 349-363 (1980).

3. R. Radmer and G. M. Cheniae, in Topics in Photosynthesis, J. Barber, Ed., Vol. 2, ElsevierExcerpta Medica, New York, 1976, pp. 303-368.

4. J. Amesz, Biochim. Biophys. Acta 726, 1-12 (1983).

5. G. M. Cheniae and I. F. Martin, Biochim. Biophys. Acta 197, 219-239 (1970).

6. R. E. Blankenship, G. T. Babcock, and K. Sauer, Biochim. Biophys. Acta 387, 165-175 (1975).

7. T. Yamashita, T. Tsuji, Y. Yosio, and T. Giiti, Plant Cell Physiol. 13, 353-364 (1972).

8. T. Yamashita and W. L. Butler, Plant Physiol. 43, 1978-1986 (1968); 44, 435-538 (1969).

9. T. Yamashita, T. Junko, and T. Giti, Plant Cell. Physiol. 12, 117-126 (1971).

10. R. E. Blankenship and K. Sauer, Biochim. Biophys. Acta 357, 252-266 (1974).

11. P. Horton and E. Croze, Biochim. Biophys. Acta 462, 86-101 (1977).

12. G. M. Cheniae and I. F. Martin, Biochim. Biophys. Acta 502, 321-344 (1978).

13. S. Izawa, R. Heath, and G. Hind, Biochim. Biophys. Acta 180, 388-398 (1969).

14. W. D. Frasch, Ph.D dissertation, University of Kentucky, 1980, available from University Microfilms, Order No. 8110207.

15. G. M. Cheniae and I. F. Martin, Biochim. Biophys. Acta 153, 819-837 (1968).

16. G. M. Cheniae and I. F. Martin, Brookhaven Sym. Biol. 19, 406-416 (1966).

17. R. L. Heath and G. Hind, Biochim. Biophys. Acta 189, 222-233 (1969).

18. G. M. Cheniae and I. F. Martin, Biochim. Biophys. Acta 253, 181-182 (1971).

19. R. Radmer and G. M. Cheniae, Biochim. Biophys. Acto 253, 182-186 (1971).

20. J. L. Casey and K. Sauer, Biochim. Biophys. Acta 767, 21-28 (1984).

21. D. F. Ghanotakis, J. N. Topper, G. T. Babcock, and C. F. Yocum, FEBS Lett. 170, 169-173 (1984).

22. Y. Yamamoto and M. Nishimura, Biochim. Biophys. Acta 724, 294-297 (1983).

23. B. Kok, B. Forbush, and M. McGloin, Photochem. Photobiol. 11, 457-475 (1970).

24. G. C. Dismukes and Y. Siderer, FEBS Lett. 121, 78-80 (1980).

25. G. C. Dismukes and Y. Siderer, Proc. Natl. Acad. Sci. USA 78, 274-278 (1981).

26. Ö. Hansson and L. A. Andreasson, Biochim. Biophys. Acta 679, 261-268 (1982).

27. G. W. Brudvig, J. L. Casey, and K. Sauer, Biochim. Biophys. Acta 723, 366-371 (1983).

28. J. L. Zimmerman and A. W. Rutherford, Biochim. Biophys, Acta 767, 160-167 (1984).

29. J. A. Kirby, D. B. Goodin, T. Wydrzynski, A. S. Robertson, and M. P. Klein, J. Am. Chem. Soc. 103, 5537 (1981).

30. M. P. J. Pulles, H. J. Van Gorkom, and J. G. Willamsen, Biochim. Biophys. Acta 449, 536-540 (1976).

31. B. Velthuys, in Photosynthesis II. Electron Transport and Photophosphorylation, G. Akoyunoglou, Ed., Balaban Int. Sci. Service, Philadelphia, 1981, pp. 75-85. 
32. G. Renger and W. Weiss, Biochim. Biophys. Acta 722, 1-11 (1983).

33. J. T. Dekker, H. J. Van Gorkom, M. Brok, and L. Ouwehand, Biochim. Biophys. Acta 764, 301309 (1984).

34. J. P. Dekker, H. J. Van Gorkom, J. Wensink, and L. Ouwehand, Biochim. Biophys. Acta 767, 19 (1984).

35. J. P. Dekker, J. J. Plijter, L. Ouwehand and H. J. Van Gorkom, Biochim. Biophys. Acta 767, 176-179 (1984).

36. G. C. Dismukes and Y. Siderer, Proc. Natl. Acad. Sci. USA 78, 274-278 (1981).

37. G. C. Dismukes, K. Ferris, and P. Watnick, Photobiochem. Photobiophys, 3, 243-248 (1982).

38. R. S. Nyholm and A. Turco, Chem. Ind. (London) 74, (1960).

39. D. T. Sawyer, M. E. Bodini, L. A. Willis, T. L. Riechel, and K. D. Magers, Adv. Chem. Socs. 162, 330-349 (1977).

40. W. M. Holloway, Jr., T. J. Giordano, and D. R. Peacor, Acta Crystallogr B28, 114-117 (1972).

41. O. K. Mel'nikov, B. N. Litvin, and S. P. Fedosova, Gidroterm. Sin. Krist. 167-174 (1968).

42. J. H. Van Vleck, The Theory of Electric and Magnetic Susceptibilities, Oxford University Press, Oxford, 1932, Chap. 12.

43. E. M. Meyers, Ph.D. dissertation, The University of Michigan, 1975, available from University Microfilms, Ann Arbor, Michigan, Order No. 76-9468.

44. V. E. Simmons, Ph.D. dissertation, Boston University, 1963, available from University Microfilms, Ann Arbor, Michigan, Order No. 63-5910.

45. T. H. Gould, Jr., Ph.D. thesis, The University of Michigan, 1974, available from University Microfilms, Ann Arbor, Michigan, Order No. 74-15, 734.

46. T. H. Gould, Jr. and D. H. Vincent, J. Phys. (Paris) Colloq. 6, 315-319 (1974).

47. W. R. Dunham, Ph.D. dissertation, The University of Michigan, 1970, available from University Microfilms, Ann Arbor, Michigan, Order No. 70-19, 588.

48. A. Earnshaw, Introduction to Magnetochemistry, Academic Press, New York, 1968, pp. 72-82.

49. B. Figgis, Introduction to Ligand Fields, Interscience, New York, 1966.

50. P. W. Selwood, Magnetochemistry, Interscience, New York, 1956.

51. F. E. Mabbs, Magnetism and Transition Metal Complexes, Halsted Publishers, New York, 1975.

52. G. M. Bankcroft, A. G. Maddock, and R. G. Burns, Geochim. Cosmochim. Acta 31, 2219-2246 (1967).

53. T. H. Moss, A. J. Bearden, R. G. Bartsch, M. A. Cusanovich, and A. San Pietro, Biochemistry 7, 1591-1596 (1968).

54. S. I. Gurvich, L. B. Zubkov, and L. S. Galetskii, Int. Geol. Rev. 8, 404-415 (1966).

55. L. Corliss, N. Elliot, and J. Hastings, Phys. Rev. 104, 924-928 (1956).

56. T. Yamashita and G. Tomita, Plant Cell Physiol. 17, 571-582 (1976).

57. T. Yamashita and G. Tomita, Plant Cell Physiol. 15, 69-82 (1974).

58. T. Yamashita and G. Tomita, Plant Cell. Physiol. 16, 283-296 (1975).

59. J.-M. Briantais, C. Vernotte, J. Lavergne, and C. J. Arntzen, Biochim. Biophys. Acta 461, 6174 (1977).

60. G. Palmer, W. R. Dunham, J. A. Fee, T. Hzuka, and T. Yonetani, Biochim. Biophys. Acta 245, 201-207 (1971).

61. S. R. Cooper, G. C. Dismukes, M. P. Klein, and M. Calvin, J. Am. Chem. Soc. 100, 7248-7252 (1978).

62. P. M. Plaksin, R. C. Stoufer, M. Mathew, and G. J. Palenik, J. Am. Chem. Soc. 94, 2121-2122 (1972).

63. A. J. Bearden and W. R. Dunham, in Iron-Sulfur Proteins, W. Lovenberg, Ed., Academic Press, New York, Vol. II, 1973, Chap. 6.

64. C. E. Johnson, R. C. Bray, R. Cammack, and D. V. Hall, Proc. Natl. Acad. Sci. USA 63, 12341238 (1968).

65. P. G. Debrunner, C. E. Schulz, G. Feher, and M. Y. Okamura, Biophys. J. 15, 226a (1975),

66. J. H. A. Nugent, B. A. Diner, and M. C. W. Evans, FEBS Lett. 124, 241-244 (1981).

67. I. E. Grey and H. Steinfink, Inorg. Chem. 10, 691-696 (1971).

68. A. Danielian and K. W. H. Stevens, Proc. Phys. Soc. (London) 77, 124-128 (1961).

69. W. H. Brumage, C. R. Yarger, and C. C. Lin, Phys. Rev. 133, A765-A767 (1964).

70. D. S. McClure, J. Chem. Phys. 39, 2850-2855 (1963).

Received November 1, 1984; revised and accepted January 18, 1985 